\title{
Sociological Reflection on the Construction of Water Ecological Civilization City in Shaanxi Province
}

\author{
Zhao Xiao'e \\ Xi'an Municipal Party School of the CPC, Xi'an 710054, China
}

Keywords: Shaanxi Province; water ecological civilization city; sociology

\begin{abstract}
Water, as an indispensable element of ecological system, directly relates to the economic, social and its own development of the city. Under the general plan of the Party Central Committee, Shaanxi Province issues a series of local law regulations and practice measures on water ecological civilization, has obtained great accomplishments in promoting the construction of water ecological civilization city, however, it also has encountered a series of new problems at the same time. In the new era of socialism modernization with Chinese characteristics, it is necessary for Shaanxi Province to build a united front cooperatively in construction of water ecological civilization city, solve problems in the process, and provide high-quality water ecological products for people.
\end{abstract}

In the new era of socialism modernization with Chinese characteristics, the Party Central Committee, with General Secretary Xi Jinping as the core, has kept pace with the times, with pioneering and innovative spirit, and proposed the overall national construction layout of the "five-sphere integrated plan" to promote coordinated economic, political, cultural, social and ecological advancement, and the development concept of "Beautiful scenery is the gold and silver mines”, to draw a beautiful blueprint for the construction of ecological civilization with water ecological civilization as main content. Under the general plan of the Party Central Committee, Shaanxi Province issues a series of local law regulations and practice measures on water ecological civilization to provide guarantee and point out direction for the construction of water ecological civilization city of local cities in Shaanxi Province.

\section{Achievements obtained in the construction of water ecological civilization city in Shaanxi Province}

According to sociology, a city is not only an economic system, but also a social, humanistic, and ecological system. ${ }^{[1]}$ Water, as an indispensable element of ecological system, directly relates to the economic, social and its own development of the city. After years of unremitting efforts and promotion, the construction of water ecological civilization city of Shaanxi Province has obtained considerable achievements. First of all, the pilot project of national water ecological civilization city has been verified. Xi'an was included in the first batch of pilot project of 46 water ecological civilization cities in the whole country in 2013, and has been verified successfully in August, 2017. Secondly, provincial pilot districts and counties have been established. In 2015, Shaanxi Province identified Lin Tong, Mei County, Huang Ling, Xixiang County, Zhashui County as provincial pilot districts and counties to lay a solid micro-foundation for the construction of water ecological civilization city in the whole province. Thirdly, the construction of water-conserving society has been accomplished. During the $12^{\text {th }}$ Five-Year Plan, Xi'an, Yulin, Yan'an, Baoji, Hsienyang have passed the inspection of national water-conserving model city, and Yangling, Yaozhou, Pucheng, Linwei, Baota, and Lveyang have accomplished the pilot construction of provincial water-conserving society. Fourthly, 26 provincial demonstration parks of water and soil conservation have been identified. Since 2012, Shaanxi Province has set 26 provincial demonstration parks of water and soil conservation in three batches, including various geomorphic features from Loess Plateau to Guanzhong Plain to Qinling-Daba Mountain Areas. At the same time, 7 demonstration parks have obtained the title of "National Water and Soil Conservation Technology Demonstration Park”, including Xi'an Hancheng Lake, Maijiegou in Jingyang, Xianyang, Donggou 
in Sanyuan, Xianyang, Peach Flower Valley in Danfeng, Shangluo, Cherry Valley in Xixiang, Hanzhong, and Liangjiahe in Yanchuan, playing an important role in water and soil conservation in the whole province as models. Fifthly, several engineering projects of water ecological civilization have been constructed. Such diversion projects as Hanjiang to Weihe River Project, Qianyou to Shibianyu River Project, and Hongyan to Shitou River Project greatly alleviate the water shortage in Guanzhong area. Water conservancy projects, such as "Eight Rivers to Xi'an", comprehensive treatment of Weihe, and water ecological restoration in Guanzhong area dramatically improve the water ecological environment in Guanzhong area. ${ }^{[2]}$ Besides, 35 national water conservancy areas with different characteristics including Gaoxigou in Mizhi County, Qianceng River in Langao County, Hancheng Lake, Bawei Guanzhong Culture Water Conservancy in Mei County have become demonstration projects to enhance urban ecological environment for citizens to travel in holidays. Sixthly, achievements in the construction of sponge city have been obtained. Xi Xian New Area has been included in the first batch of 16 national sponge city construction pilot cities in the whole country as the only one selected city in Northwest China, gathering experience for the construction of sponge city in Shaanxi Province. Seventhly, law and regulation system of water ecological civilization has been formed. From Act of Shaanxi Province Water and Soil Conservancy, Act of Shaanxi Province Weihe River Basin Management, Act of Shaanxi Province Hydrology, and Act of Shaanxi Province Underground Water, to Water Law of the People's Republic of China, and Implementing Measures of Collection Management of Compensation Fee for Shaanxi Province Water and Soil Conservancy implemented, Shaanxi Province continuously improves and develops law regulations for the construction of water ecological civilization to ensure the construction of water ecological civilization city. Eighthly, innovation has been conducted on mechanism of rural water supply engineering management. 29 rural water supply projects in 7 impoverished counties, including Lveyang and Zhenba County in Hanzhong, Southern Shaanxi, Hanbin District, Ziyang and Hanyin County in Ankang, Zhashui and Danfeng County in Shangluo, have implemented the pilot of "quantification and empowerment", with the principle of "confirmation, quantification, empowerment and stimulation” to ensure the clear property rights, well-organized management and abundant funds in rural water supply projects to make it beneficial for peasants.

\section{New problems in the construction of water ecological civilization city in Shaanxi Province}

New opportunities bring new challenges, and new development creates new problems. With the steady improvement of water ecological environment in Shaanxi Province, a series of new contradictions and problems occur.

(1) Contradictions in regional planning. Shaanxi Province has issued general planning and scheme in the treatment, management and conservation of water ecology, however, each city formulates specific implementing plan of water ecological civilization city according to general planning. But these plans mainly just pay attention to their own convenience of management and effects of treatment, but scarcely consider disadvantageous influence on other cities, which causes contradictions between cities or counties, and more seriously deteriorates the overall water ecology in the entire province, contrary to the law of nature and far away from sustainable development.

(2) Criticisms on artificial waterscape. There are some projects such as river, lake scene or waterscape parks in the construction of water ecological civilization city, which optimizes urban infrastructure, improves urban image, beautifies urban environment, satisfies increasing life requirements of citizens and improves life quality. However, the construction of these landscapes requires a considerable amount of manpower, material resources, and financial resources. In addition, such artificial landscapes are not as close and harmonious as the natural landscapes. As a result, many citizens think that this is not livelihood project, but vanity project. It is still difficult to eliminate criticism and gain the understanding and support of the vast majority of people.

(3) Unstandardized evaluation index. For the nation as a whole, a set of the same evaluation standard can only ensure the fairness and reasonability of the selection of water ecological civilization city. However, due to varied geographical, climatic and social status in places, there exist differences in water environment of different places. In addition, some areas are affected by 
economic structure and long-term unreasonable management and protection in water ecology, therefore, it is nearly impossible to reach a set index standard. Thus, there is a deep contradiction between the unified evaluation system of water ecological civilization city and different evaluation system required in each area.

(4) Unreasonable system and mechanism. First of all, difficult overall coordination because of decentralized rights and liabilities. The shirk responsibility of relationship between authority and responsibility in departments of the projects of water ecological civilization city has a negative influence on the promotion of projects. Secondly, lack of personnel allocation for the heavy workload. The phenomenon of one person undertaking the workload of several people causes the fact that a large number of specific affairs cannot be specified to certain person, and especially there is a shortage of vehicle allocation after the official cars reform in remote mountainous region with inconvenient traffic, which brings difficulties to management and protection of water ecology. Thirdly, the lack of reward mechanism and insufficient implementation of “Three Mechanism”. Many grass-roots cadres are afraid of making mistakes, and have the least passion for work, and the idea of "doing nothing is better than doing something" is spreading in contingent of cadres.

(5) Lack of foreseeability in construction planning. With the rapid development of urbanization, the urbanization rate of Shaanxi Province has exceeded 50\% at present, and will reach 60\% in 2020 according to Shaanxi Province Population Development Planning (2016-2030), which requires immediately perfect supporting public utilities. However, supporting infrastructure of water ecological civilization in Shaanxi Province cannot be matched with the development speed, which leads to the emergency of water environment capacity and weakening ability to balance the water ecological system.

(6) Low usage of recycled water. Shaanxi Province has a total water resources of 44.5 billion cubic meters, ranking $19^{\text {th }}$ among all provinces (cities and districts) in the country, and per capita water resources are $63 \%$ of the national average. In the overall shortage of water resources, the utilization of secondary or recycled water is not high in the cities of Shaanxi. Taking Xi'an as an example, the utilization rate of sewage is only $17.8 \%$, which is only $1 / 2$ of the utilization rate of $35 \%$ of most cities in eastern China, and only $1 / 4$ of the utilization rate of $70 \%$ of recycled water in developed countries in the world.

(7) Insufficient publicity of water ecological civilization concept. The concept of harmonious development of people and water has not yet been universally rooted in the minds of the broad masses. Many people have low levels of water ecological culture in an "illiterate, semi-literate" state. Even some public servants have surprisingly poor awareness of water ecological civilization. Therefore, for people, especially public officials, it is imperative and important to strengthen education on water ecological civilization and water ecological culture.

\section{Sociological reflection on the construction of water ecological civilization city in Shaanxi Province}

The 19th CPC National Congress strengthens that the modernization we are building is the modernization with the harmonious coexistence of human and nature, and it is necessary to provide more high-quality ecological products to satisfy the growing needs for beautiful ecological environment of people. Abundant clean water resources is high-quality water ecological products. In the construction of water ecological civilization, it is essential for Shaanxi Province to solve problems, overcome obstacles and forge ahead to provide high-quality water ecological products for people.

\subsection{Give full play to the cooperation to establish the united front for the construction of water ecological civilization city}

Firstly, one heart and one mind in thinking to firmly establish the harmonious development concept of human and water. On one hand, to popularize education on water ecological civilization. To create green schools, incorporate the basic education of water ecological civilization into the compulsory education in primary and secondary schools, cultivate the awareness of protecting the 
water ecological environment, and conserve water resources from an early age. To create green government to incorporate in-depth education such as inspiring education on water ecological civilization into the continuing education of party and government leading cadres, through research and discussion, stimulate the potential of leading cadres and form a government report on water ecological civilization with high reference value. To create green community, incorporate the guiding education on the water ecological civilization into the propaganda of the special topics of the community and street offices, and enhance consensus education so that the relevant water ecology civilization knowledge can be popularized in all people. On the other hand, to strengthen multi-channel publicity. Media such as broadcast, television, newspapers and periodicals, Internet and etc. can be applied to widen the publicity of water ecological culture.

Secondly, one heart in action to gather concerted efforts. On one hand, headquarters of joint prevention and control shall be established in central cities to coordinate the construction of water ecological civilization, with the mayor as the chief, and the head of district and counties as members to be responsible to the mayor; on the other hand, the general headquarters of joint prevention and control of water ecological civilization shall be established with Xi'an as the center, local headquarters comply with the allocation of Xi'an, with provincial governor as the chief, and mayors of cities as members to be responsible to the provincial governor. The main function of joint prevention and control headquarters is to build the exchange and communication platform for sharing of information, experience and risks, to coordinate the contradictions in management and protection of water ecology, water environment and water safety in cities, districts and counties, and to discuss major measures and resolutions on the construction of water ecological civilization city.

\subsection{Formulate systematic and perfect management and protection of water ecology}

To scientifically formulate Management Planning of Water Environment, Allocation Planning of Water Resources, and Management Planning of Water Ecology according to law and regulations on water like Water Pollution Control Action Plan and the objectives of water ecological civilization ${ }^{\mathbf{3 1} \text {, }}$ to play a guiding role in water pollution treatment and prevention, and allocation, protection and management of water resources in the construction of water ecological civilization city. A scientific and reasonable manpower development plan shall be issued urgently, and manpower is fully guaranteed, to ensure authority with responsibility and position with personnel, particularly personnel are in place at the grassroots level. The temporary employees are managed by labor service companies and, if possible, some of the work is outsourced to professional companies to make up for the shortage of personnel, and to ensure that special positions are equipped with professional personnel to ensure that problems are solved in a timely manner.

\subsection{To strive for demonstration city of water ecological civilization}

On one hand, to construct "water ecological civilization city- water ecological civilization province" according to the ecological civilization pattern of "Three Grades, Five Levels". To keep pace with the thinking of "municipal- provincial- national" ecology, and system of "ecological village- ecological town- ecological county (district)- ecological city- ecological province”, easy to difficult, take the experience gained at one unit and popularize it in a whole area and conduct the basic construction of ecological civilization city. On the other hand, to innovate the mode of demonstration city of water ecological civilization. To conduct more investigation and researches, based on self-advantages, create new methods and innovate modes, such as, "A Total of Five Water Treatment" of Zhejiang Province, comprehensive treatment of point source treatment, non-point source treatment, sewage interception engineering, river regulation, water plant and flow velocity in Nanming River in Guiyang, ${ }^{\mathbf{4} \mathbf{1}}$ which requires us to conduct research and obtain inspiration to construct water system in Guanzhong area.

\subsection{To strengthen the construction of water-conserving city}

According to sociological function theory, the equilibrium is the norm and essential feature of a social system. When it is disturbed by external environment or changes occur within the system, the 
original equilibrium is broken and the social system is internally adjusted to achieve a new equilibrium. Faced with the rapid development of urbanization and the continuously increasing population, it is necessary to focus on the development of water resources, increase the utilization of flood water and secondary water, actively build water-conserving cities, improve the planned water use system, realize quota management of water resources, and promote step toll system to promote self-cultivation of the awareness of water-saving for people.

\subsection{To implement comprehensive evaluation index}

The specific analysis of specific issues is the basic requirement of the sociological research on practical issues. The index system is essentially a social norm that restricts a certain area to become a structure with internal order. On April 11, 2016, the Ministry of Water Resources issued the Guidelines for the Evaluation of Water Ecological Civilization Cities, which provided important professional guidance for the creation of water ecological civilization cities nationwide, and provided technical standards for evaluating the effectiveness of water ecological civilization cities. However, it is also necessary to take into account the specificities of each region and establish a set of scientific and reasonable evaluation systems with sound function and simple operation.

\subsection{To implement river chief system, and develop water compensation system of water resources in Southern Shaanxi}

On one hand, to resolutely implement the river chief system, ${ }^{\mathbf{5} 1}$ refine the scope of the authority and responsibility of the river chief, improve equipment and facilities, and improve management capabilities and overall quality. At the same time, to actively innovate the main body of the river chief, mobilize experts, enterprises, and citizens to serve as the river chief, improve the professional level of river management, and truly realize the river management by river chief. On the other hand, to actively develop ecological compensation mechanism in water source district in the middle line of the south-to-north water transfer project. The principle of profitability is one of the principles that sociology must follow to solve real problems. In the process of "A river of clean water to Beijing-Tianjin," it is necessary to formulate the "economic compensation for the development and use of cross-basin water resources" to protect the sincere cooperation between benefited party and the paying party. At the same time, the benefited and the paying party can form a support relationship, and the benefited party provides intellectual support and material support for the paying party to improve the economic vitality and living conditions of the paying party.

In conclusion, faced with real world, to solve social problems in the reality is the most basic requirement for each intellectual in sociology. To construct a social system with harmony of human and water and realize a positive interaction between human and natural environment is an important part in the goal of "chasing and surpassing" for Shaanxi Province. Every ordinary citizen as a city cell has the responsibility and obligation to actively explore the laws of social development, and make due contributions to the construction of water ecological civilization city and a Shaanxi with the harmony of human and water.

\section{Acknowledgements}

Funding Project: Shaanxi Province Social Science Funding Project (2017E005).

\section{References}

[1] Sociology. [Germany] Georg Simmel. Lin Rongyuan translate. Huaxia Publishing House. 2002-1-1version.

[2] Xi'an Mode of Universe Water Ecological Construction [N]. Dai Jianchao. Yellow River News. 2018-02-10(002).

[3] Reflection Related to Water Ecological Civilization Construction [J]. Chen Mingzhong. China Water Resources. 2013(15). 
[4] Deeply Implementing the Comprehensive Planning of Yangtze River Basin, Strenuously Promoting the Construction of Water Ecological Civilization in the Basin [J]. Liu Yaming. Yangtze River. 2013(10).

[5] Study on Legal Guarantee Measures of Construction of Water Ecological Civilization City [J]. Ye Youhua, Jin Banglin. Yangtze River. 2016(01).

About the author: Zhao Xiao'e (1979- ), female, Zhen'an, Shaanxi, lecturer of Xi'an Municipal Party School of the CPC, research direction: politics, sociology. 